\title{
Relationship Between Immaterial Capital and Performance of Islamic Banks: Empirical Study of Listed Banks in Bahrein and United Arab Emirates
}

\author{
Fadma El Mosaid \\ National School of Applied Sciences, Ibn Zohr University, PO box 1136, Agadir, Morocco
}

\begin{abstract}
The aim of this study is to investigate the relationship between immaterial capital and financial performance of eighteen listed Islamic and conventional banks in Bahrein and United Arab Emirates for the year 2018. Data is obtained from annual reports of banks. The approach used to analyze the efficiency of banks is Value added intellectual coefficient (VAIC). The financial performance of the selected banks for this study is evaluated by ROA and ROE measures. The immaterial capital (and its components human capital and structural capital) of banks have been analyzed and their impact on financial performance has been estimated using multiple regression technique. The results show that the VAIC value is the same for Islamic banks and conventional banks. The findings show that VAIC is positively associated with ROA while the three components of VAIC showed mix results on banks' performance. In the context of knowledge economy, the VAIC approach may be convenient for the banks and policy makers to integrate the immaterial capital in the decision-making process. A future study including listed banks in all countries of Gulf Cooperation Council (GCC) could provide a better evaluation of the impact of immaterial capital on financial performance for the banking sector, especially Islamic banking.
\end{abstract}

Keywords: Immaterial Capital, Performance, Islamic Banks, Efficiency, Value Added Intellectual Coefficient (VAIC)

DOI: $10.7176 / \mathrm{JESD} / 11-6-07$

Publication date:March $31^{\text {st }} 2020$

\section{Introduction}

Immaterial capital called also intellectual capital or intangible capital (IC) (Montalan \& Vincent, 2010, p:2) is getting importance in current knowledge economy and contribute to improve productivity, performance and competitiveness of organizations. The immaterial capital consists of human resources, human resources research and development, organizational structure and processes technology and rights related to intangible property, consumer networks and software (Al Matarneh, 2014). Many essays were done to develop a commonly recognized definition of Immaterial capital. Klein and Prusak (1994) defined IC as intangible material that can be formalized, captured and employed to provide higher value assets. Stewart (1997) defines IC as the new wealth of organizations and defends that the intangible resources, like knowledge, information and experience, are the base of wealth creation. Edvinsson and Malone (1997) and Sullivan (2000) define IC as knowledge that can be transformed in value. Hence, intangible capital can be recognized as the collective knowledge related to organizational and personnel practices and relationships of an organization (Stewart, 1997; Choo \& Bontis, 2002; Kong, 2008). Intangible capital can be defined as the economic value of three types of intangible assets of an organization namely human capital, organizational capital and social capital. In this context, it is argued that taken collectively, physical, human, and organizational capital, contribute to sustain development of firms and organizations (Al Matarneh, 2014). Considering the intangible being of knowledge, numerous perceptions are anticipated by scholars and each attempt to apprehend a particular phenomenon. For all that, successful companies admit that capitalizing in knowledge is crucial in order to generate high value products and services. (Al Matarneh, 2014).

In the case of Islamic banks which attempt to be competitive not only among Islamic finance but also regarding conventional banks, their performance is induced by both internal and external determinants. Internal one could be bank size, capital adequacy, liquidity ratio, overhead costs, liability portfolio diversification, human resources and ownership (Ramlall, 2009; Setyawati, 2016; Suroso et al., 2017). Intellectual capital is all the knowledge owned by human resources of organizations that can engender added value. According to Cantu et al. (2009), it is possible for banks to have high intellectual capital through qualified and competent human resources. Several researches have been done on intellectual capital and institute empirical affirmation that intellectual capital boost organization performance (Chen et al., 2005; Gan and Saleh, 2008).

The purpose of this study is to analyze the relationship between immaterial capital and financial performance in the sector of banking especially Islamic banks. The nature of the banking sector business and Islamic banking mainly involves highly intellectual personnel because the industry depends for its survival on both human capital and customer capital (Suroso et al., 2017). The section two is allocated to a literature review highlighting mean studies related to our topic. Section three presents data, methodology and variables used to solve our issue. 
Findings and discussion are given in section four then we conclude.

\section{Literature Review}

Al Matarneh (2014) aimed to investigate the effect of intangible capital on the financial performance and market value of Jordanian companies. For this reason, he used an empirical study drawn from 51 listed companies in Amman Stock Exchange from 2007 till 2012. The results attained illustrate that there is a significant relationship between intangible capital with market value and the financial performance of all the active companies.

Hasan et al. (2017) explored, empirically, the relationship between intellectual capital and financial performance of twenty-seven private commercial banks for the year 2013 in Bangladesh. The results show that both VAIC and its components have a significant relationship with profitability. The authors found that components of VAIC are significant predictor of bank's profitability for either conventional and Islamic banks.

Kamal et al. (?) conducted their research in order to investigate the relationship between the level of intellectual capital efficiency using VAIC approach with the commercial banks' performance in Malaysia. The Results admit relationship between intellectual capital and performance of 18 commercial banks in Malaysia. Furthermore, the results show significant impact of component of VAIC namely Capital employed efficiency (CEE), Human capital efficiency (HCE) on banks performance. The authors argued that intellectual capital is crucial to improve productivity of firms. The study suggests that the importance of intellectual capital should be highlighted not only to the commercial banks but also to the emerging market of Islamic banks in Malaysia or any other industries for future research.

Latif et al. (2012) tried to examine the relationship between intellectual capital measured by VAIC method and corporate performance measured by three traditional dimensions of: profitability, productivity, and market valuation of Islamic and conventional banks of Pakistan. The results relating to the correlation between the three components of VAIC and measures taken for corporate performance namely profitability, productivity and market valuation are mixed. The authors state a significant relationship between $\mathrm{HCE}$ and almost all variables of corporate performance, in case of Islamic banks, and a significant relationship is found between CEE and all variables of performance in case of conventional banks. In other words, HCE is the principal forcaster of corporate performance of Islamic banks, while the CEE is the main predictor of corporate performance in the case of conventional banks.

Muthia et al. (2017), aimed to evaluate the IC development model to increase the performance of Islamic banking in Indonesia. The authors found that the IC component has a positive and significant effect on the performance of Islamic banking in Indonesia. A relationship exists between two components of IC, namely HCE and CEE and the performance of Islamic banks, whereas SCE has no impact on Islamic banks performance. Moreover, the authors state a higher influence of HCE on Islamic banking performance compared with CEE.

Nawaz (2017) conducted his research to determine, empirically, the influence of intellectual capital (IC) and Shariah governance on economic performance of 47 Islamic banks operating in the Gulf Cooperation Council (GCC) region before and after financial crisis. The results indicate that higher IC efficiency sustain Islamic banks to increase their chances of persistence before and after crisis. Furthermore, the author sustains that higher IC efficiency helps Islamic banks to maintain their profitability. According to the author, IC is the principal defense for Islamic banks facing to negative shocks.

Setianto and Sukmana (2016) attempted to investigate empirically the relationship between the Intellectual Capital (IC) efficiency and Islamic banks performance in Indonesia and Malaysia. The authors affirm that there are significant differences in intellectual efficiency results, where Islamic Banks in Malaysia have revealed better VAIC values compared to Islamic banks in Indonesia. The results show also a positive relationship between HCE and performance of banks, while SCE is not related to Islamic bank performance. The results show as well a positive relationship between CEE and performance of banks both in Indonesia and Malaysia.

Suroso et al. (2017) studied the impact of intellectual capital and corporate governance on the financial performance in the case of Islamic banks. The authors used VAIC approach to evaluate the intellectual capital efficiency and return on asset (ROA) and asset growth (AG) to evaluate the performance. The results affirm a positive and significant impact of intellectual capital and corporate governance on ROA, and does not affect the growth of corporate assets (AG).

Taha et al (?) aimed to examine the influence of intellectual capital on the financial performance of banks in Pakistan. The authors employed the VAIC approach to analyze the efficiency of banks and ROA as a measure of financial performance of the banks. The results show that VAIC score of conventional banks is higher compared Islamic banks. HCE is the main predictor of the intellectual capital performance of banks operating in Pakistan. The results affirm a positive relationship between VAIC and performance evaluated by ROA while components of VAIC presented mix results on banks' performance.

\section{Data and Methodology}

The aim of this research is to investigate the relationship between immaterial capital and financial performance in the case of banks specifically Islamic banks. In this purpose, we conduct an empirical research on eighteen listed 
banks in Bahrein and United Arab Emirates for the year 2018. The hypothesis to verify are:

H1: Immaterial capital impact positively on return on asset (ROA)

$\mathrm{H} 2$ : Immaterial capital impact positively on return on equity (ROE)

The sample of our study consists of listed banks in Bahrein and United Arab Emirates (UAE) which are eighteen banks ten in UAE and eight in Bahrein. Data is collected from annual reports of selected banks.

Table 1. List of selected banks for the research

\begin{tabular}{|l|l|}
\hline Bahrein & UAE \\
\hline Ahli United Bank (AUB) & Abu Dhabi Commercial Bank (ADCB) \\
\hline Al Baraka & Abu Dhabi Islamic Bank (ADIB) \\
\hline Al Salam & Commercial Bank of Dubai (CBD) \\
\hline Bahrein Islamic Bank (BISB) & Dubai Islamic Bank (DIB) \\
\hline Bank Bahrein and Kuwait (BBK) & Emirates NBD Bank (ENBD) \\
\hline Ithmaar & Mashreq \\
\hline Khaleeji & National Bank of Ras Al-Khaymah (RAK) \\
\hline Nationa Bank of Bahrein (NBB) & Union National Bank (UNB) \\
\hline & First Abu Dhabi Bank (FAB) \\
\hline & Sharjah Islamic Bank (SIB) \\
\hline
\end{tabular}

The immaterial capital (IC) performance of banks is measured through the value-added intellectual coefficient (VAIC) methodology of Public $(1998,2000)$. The VAIC is calculated as follows:

$$
\mathrm{VAIC}=\mathrm{HCE}+\mathrm{SCE}+\mathrm{CEE}(1)
$$

The financial performance of the selected banks for this study is evaluated by two measures namely Return on Asset (ROA) and Return on Equity (ROE).

This study uses the model presented in Figure 1 to examine the impact of intellectual capital on financial performance using multiple regression.

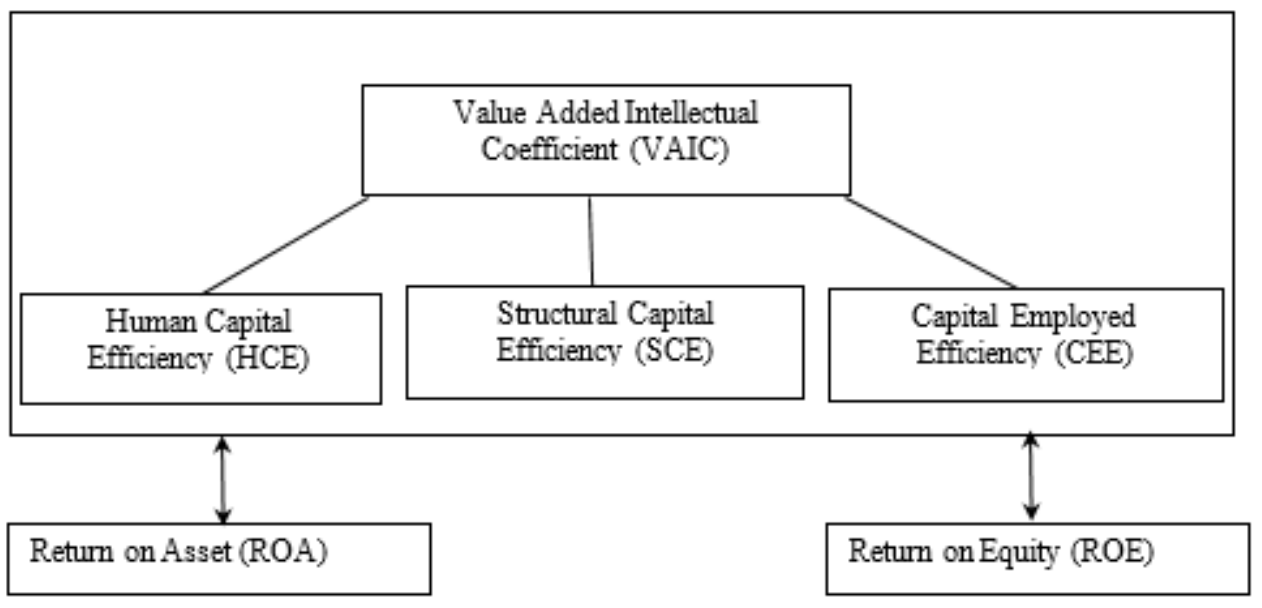

\section{Measurement of the variables}

Figure 1: Theorical model for testing the relationship among variables

- Dependent variables

Previous studies have used Return on Asset (ROA) or/and Return on Equity (ROE) to assess the financial performance of banks (Chen et al., 2005; Suroso et al., 2017, Taha et al.,?). This study uses both measures of financial performance defined as follows:

- Independent variables

$$
\begin{aligned}
& \text { Return on Assets }(\text { ROA })=\text { Net Income } / \text { Total Assets } \\
& \text { Return on Equity }(\text { ROE })=\text { Net Income / Total Equity }
\end{aligned}
$$

VAIC and its components, HCE, SCE, and CEE, are independent variables of this study.

VAIC is evaluated through the measure of value added (VA) which can be expressed as follow:

$$
\mathrm{VA}=\text { Output - Input (Except salaries) }
$$

Human Capital Efficiency: Human Capital (HC) is defined as personnel costs (Public, 1998, 2000). It is measured by the following formula:

$$
\mathrm{HCE}=\mathrm{VA} / \mathrm{HC}
$$

Structural Capital Efficiency: Structural capital (SC) includes immaterial capital items such as strategy, organizational networks (Public, 1998, 2000). SC and SCE are calculated as follow:

$$
\begin{aligned}
& \mathrm{SCE}=\mathrm{SC} / \mathrm{VA} \\
& \mathrm{SC}=\mathrm{VA}-\mathrm{HC}
\end{aligned}
$$


Capital Employed Efficiency: Public $(1998,2000)$ argues that IC cannot create value on its own, thus it must be associated with capital (physical and financial) employed (CE). CEE is calculated by the formula above:

$$
\mathrm{CEE}=\mathrm{VA} / \mathrm{CE}
$$

Value Added Intellectual Coefficient (VAIC): The three components of intellectual capital are therefore combined to measure VAIC:

- Control Variable

$$
\mathrm{VAIC}=\mathrm{HCE}+\mathrm{SCE}+\mathrm{CEE}
$$

Size is included, as a control variable, in the current measurement model to minimize the impact of another variable that explains observed relationships with banks performance.

$$
\text { Size }(\mathrm{Sz})=\text { Logged Total Assets }
$$

- Empirical Models

Following Public (2000), models of this study are formulated as follow:

Model 1: $\left\{\begin{array}{c}\mathrm{ROAi}=\beta 0+\beta 1 \mathrm{VAIC}+\beta 2 \mathrm{Szi}+\mathrm{ei} \\ \mathrm{ROEi}=\beta 0+\beta 1 \mathrm{VAIC}+\beta 2 \mathrm{Szi}+\mathrm{ei}\end{array}\right.$
Model 2: $\left\{\begin{array}{l}\mathrm{ROAi}=\beta 0+\beta 1 \mathrm{HCEi}+\beta 2 \mathrm{SCEi}+\beta 3 \mathrm{CEEi}+\beta 4 \mathrm{Szi}+\mathrm{ei} \\ \mathrm{ROEi}=\beta 0+\beta 1 \mathrm{HCEi}+\beta 2 \mathrm{SCEi}+\beta 3 \mathrm{CEEi}+\beta 4 \mathrm{Szi}+\mathrm{ei}\end{array}\right.$

ROA and ROE represents dependent variables and the independent variables are VAIC and size in model 1 and the components of VAIC, including human capital efficiency (HCE), structural capital efficiency (SCE) and capital employed efficiency (CEE), in model 2 in addition to control variable. HCE is the indicator of the value added (VA) efficiency of human capital whereas SCE is the indicator of the VA efficiency of structural capital and CEE is the indicator of the VA efficiency of capital employed. The model also includes control variables namely the size of bank.

\section{Finding and Discussion}

This section begins with descriptive statistics followed by a correlation analysis and conclude with regression analysis for the full sample of banks and also for Islamic and conventional banks separated.

\subsection{Descriptive Statistics}

Results related to descriptive statistics of chosen sample are given in Table 1. Financial performance is evaluated by ROA and ROE that are considered as dependent variables in the empirical models of intellectual capital. The results in table 2 show that standard deviation is low for both ROA and ROE, which state a similar profitability setting for studied banks. Then, the impact of intellectual capital on the financial performance of the banks is analyzed within a homogeneous profitability situation. By all of the VAIC components, HCE has the highest standard deviation score indicating a difference in human capital efficiency over the selected banks.

Table 2. Descriptive Statistics

\begin{tabular}{|l|l|l|l|l|l|l|}
\hline & Mean & Median & Std. Deviation & Variance & Skewness & Kurtosis \\
\hline ROA & 0.013 & 0.016 & 0.008 & 0.000 & -1.211 & 0.726 \\
\hline ROE & 0.089 & 0.109 & 0.059 & 0.004 & -0.492 & -1.304 \\
\hline HCE & 3.639 & 3.545 & 1.388 & 1.927 & 0.517 & 0.301 \\
\hline SCE & 0.677 & 0.720 & 0.153 & 0.023 & -1.413 & 1.081 \\
\hline CEE & 0.252 & 0.160 & 0.474 & 0.225 & 3.723 & 12.306 \\
\hline VAIC & 4.566 & 4.435 & 1.863 & 3.473 & 1.074 & 2.109 \\
\hline Size & 7.163 & 7.125 & 0.611 & 0.373 & 0.177 & -0.836 \\
\hline
\end{tabular}

4.2. Correlation Analysis

In order to examine for homogeneity among the variable of the study, Pearson correlation analysis was carried out. The results exposed in table 3 show statistically significant correlations among all variables except between these couples of variables (VAIC, Size), (ROA, CEE), (ROE, VAIC), (ROE, CEE), (HCE, Size), (SCE, CEE) and (CEE, Size). There is no strong significant (>.90) correlations among the three components of VAIC, assuring none homogeneity issues for model 2. 
Table 3. Correlation Analysis among Variables

\begin{tabular}{|l|l|l|l|l|l|l|l|}
\hline & ROA & ROE & HCE & SCE & CEE & VAIC & Size \\
\hline ROA & 1 & $0.819^{* *}$ & $0.777^{* *}$ & $0.904 * *$ & 0.368 & $0.748^{* *}$ & $0.492^{*}$ \\
\hline ROE & & 1 & $0.481^{*}$ & $0.701^{* *}$ & -0.115 & 0.388 & $0.737 * *$ \\
\hline HCE & & & 1 & $0.880^{* *}$ & $0.656^{* *}$ & $0.985^{* *}$ & 0.336 \\
\hline SCE & & & & 1 & 0.393 & $0.839 * *$ & $0.472^{*}$ \\
\hline CEE & & & & & 1 & $0.775^{* *}$ & -0.309 \\
\hline VAIC & & & & & & 1 & 0.212 \\
\hline Size & & & & & & & 1 \\
\hline
\end{tabular}

$* *$ sig $<0.01, * \operatorname{sig}<0.05$

\subsection{Regression Analysis}

Table 4 gives the regression results of all eighteen banks for the year 2018. The empirical results show that independent variables in Model 1 collectively explain 67.5 and 60 percent of the variance in ROA and ROE respectively. The lower value of the adjusted R2 can be explained by the non-significant correlations among few variables as explained previously. It may be observed, in table 4, that VAIC has a significant positive influence on bank's profitability while measuring by ROA. The control variable Size was found to have a significant positive impact on profitability measured both by ROA and ROE.

The relationship between components of VAIC and profitability has been measured in model 2 . The empirical results affirm that SCE and banks profitability as measured by ROA and ROE are significantly and positively correlated. The control variable Size has no a significant association with ROA and ROE in model 2.

Table 4. Regression Results (Full Sample)

\begin{tabular}{|l|l|l|l|l|}
\hline \multirow{2}{*}{ Independent Variables } & \multicolumn{4}{l|}{} \\
\cline { 2 - 5 } & Rependent Variables & \multicolumn{2}{l|}{ ROE } \\
\hline Model 1 & Coefficients & t-Statistics & Coefficients & t-Statistics \\
\hline Constant & -0.035 & $-2.393^{*}$ & -0.424 & $-3.715^{* *}$ \\
\hline VAIC & 0.003 & $4.474^{*}$ & 0.008 & 1.454 \\
\hline Size & 0.005 & $2.318^{*}$ & 0.067 & $4.107^{* *}$ \\
\hline Adjusted R2 & & 0.675 & & 0.600 \\
\hline F-value & & $15.592^{* *}$ & & 11.262 \\
\hline Model 2 & Coefficients & t-Statistics & Coefficients & t-Statistics \\
\hline Constant & -0.041 & $-2.733^{*}$ & -0.373 & $-2.762^{*}$ \\
\hline HCE & -0.003 & -1.185 & -0.014 & -0.700 \\
\hline SCE & 0.057 & $3.915^{* *}$ & 0.317 & $2.384^{*}$ \\
\hline CEE & 0.005 & 1.341 & -0.011 & -0.302 \\
\hline Size & 0.003 & 1.371 & 0.042 & 1.950 \\
\hline Adjusted R2 & & 0.846 & & 0.746 \\
\hline F-value & & $17.792^{* *}$ & & $9.563^{* *}$ \\
\hline
\end{tabular}

**sig<0.01, *sig<0.05

Additionally, the empirical model is examined for Islamic and conventional banks separately to explore any difference in the results that might emerge from the difference in their activities. The regression results of eight Islamic banks for the year 2018 are given in table 5. In model 1, the impact of VAIC on Islamic banks performance as measured by ROA is found to be positive. VAIC with control variable is found to explain 88.9 and 85.5 percent of the variation in ROA and ROE respectively. In model 2, HCE, SCE and CEE have a nonsignificant influence on both measures of performance ROA and ROE for Islamic banks while SCE had a positive influence on both measures of profitability for the total sample. 
Table 5. Regression Results (Islamic Banks)

\begin{tabular}{|c|c|c|c|c|}
\hline \multirow{3}{*}{$\begin{array}{l}\text { Independent Variables } \\
\text { Model } 1\end{array}$} & \multicolumn{4}{|c|}{ Dependent Variables } \\
\hline & \multicolumn{2}{|l|}{$\mathrm{ROA}$} & \multicolumn{2}{|l|}{ ROE } \\
\hline & Coefficients & t-Statistics & Coefficients & t-Statistics \\
\hline Constant & -0.087 & $-3.653 *$ & -0.719 & $-5.038 * *$ \\
\hline VAIC & 0.003 & $5.861 * *$ & 0.009 & 2.493 \\
\hline Size & 0.012 & $3.510^{*}$ & 0.108 & $5.218 * *$ \\
\hline Adjusted R2 & & 0.889 & & 0.855 \\
\hline F-value & & $20.091 * *$ & & $14.745 * *$ \\
\hline \multicolumn{5}{|l|}{ Model 2} \\
\hline Constant & -0.073 & $-4.153 *$ & -0.641 & $-4.705 *$ \\
\hline HCE & -0.009 & -1.246 & 0.007 & 0.124 \\
\hline SCE & 0.074 & 2.242 & 0.118 & 0.459 \\
\hline CEE & 0.018 & 1.654 & -0.015 & -0.175 \\
\hline Size & 0.009 & $3.127 *$ & 0.089 & $4.112 *$ \\
\hline Adjusted R2 & & 0.968 & & 0.929 \\
\hline F-value & & $22.388^{*}$ & & $9.884^{*}$ \\
\hline
\end{tabular}

$* *$ sig $<0.01, *$ sig $<0.05$

Regression analysis is conducted on the teen conventional banks as well. Table 6 , indicates some differences in the results as compared to the regression results of Table 4 and 5. In model 1, VAIC is found to have a positive relationship with profitability as measured by ROA. The adjusted R2 is lower indicating that VAIC can only explain 47.6 and 27.8 percent of variations in ROA and ROE respectively. VAIC have only significant relationship with ROA, while among the component of VAIC only CEE has a positive association with ROA and ROE.

Table 6. Regression Results (Conventional Banks)

\begin{tabular}{|l|l|l|l|l|}
\hline \multirow{2}{*}{ Independent Variables } & \multicolumn{4}{l}{ Dependent Variables } \\
\cline { 2 - 5 } & ROA & \multicolumn{2}{l|}{ ROE } \\
\hline Model 1 & Coefficients & t-Statistics & Coefficients & t-Statistics \\
\hline Constant & 0.035 & 2.309 & 0.171 & 1.111 \\
\hline VAIC & 0.003 & $2.412^{*}$ & 0.021 & 1.635 \\
\hline Size & -0.004 & -1.837 & 0.021 & -0.827 \\
\hline Adjusted R2 & & 0.476 & & 0.278 \\
\hline F-value & & 3.065 & & 1.346 \\
\hline Model 2 & & & & \\
\hline Constant & 0.032 & 0.700 & -0.126 & -0.242 \\
\hline HCE & 0.006 & 1.096 & 0.016 & 0.266 \\
\hline SCE & -0.050 & -0.547 & 0.064 & 0.063 \\
\hline CEE & 0.057 & $3.394^{*}$ & 0.516 & $2.708^{*}$ \\
\hline Size & -0.002 & -0.855 & 0.007 & 0.348 \\
\hline Adjusted R2 & & 0.832 & & 0.724 \\
\hline F-value & & $6.200^{*}$ & & 3.282 \\
\hline
\end{tabular}

$* *_{\text {sig }<0.01, * \operatorname{sig}<0.05}$

The regression results provided in tables 4, 5 and 6 shows that the model developed based on the Public's Intellectual Capital components are significant for the listed banks in Bahrein and UAE. Value Added Intellectual Coefficient (VAIC) is confirmed to be a durable driver of bank's performance (both conventional and Islamic Banks). VAIC has, in all situations, a significant positive impact on bank's performance measured with ROA which is the same for both Islamic and conventional banks (0.003 for ROA). In other words, an increase in VAIC by one dollar would result in an increase in ROA by 0.003 dollar. As a result, hypothesis 1 is accepted. The results are no statistically significant regarding ROE so hypothesis 2 is rejected.

The VAIC components were empirically tested to explore their impact on bank's performance in selected sample. Mixed results were found from the results showed in tables 4, 5 and 6. The first component of VAIC, HCE, has no significant association with performance measurement. While SCE was found to have a positive influence on each component of performance ( 0.057 for ROA and 0.317 for ROE) for the full sample, it became insignificant for both Islamic banks and conventional banks. Regression results in tables 4, 5 and 6 indicates that $\mathrm{CEE}$, the third component of VAIC has a significant positive association with profitability only in case of the conventional banks (3.394 for ROA and 2.708 for ROE). 


\section{Conclusion}

The present study focused on investigating the impact of intellectual capital on performance of listed banks operating in Bahrein and UAE. Hence, Public's VAIC approach was used to measure intellectual capital for banks, and financial performance was measured using ROA and ROE. This work was conducted on data from a sample of all listed banks in Bahrein and UAE, eighteen banks on 2018. Multiple regression analysis between IC measured by VAIC in model 1 and the three components of VAIC in model 2, on the one hand, and bank's performance measured by ROA and ROE, in the other hand. The results indicate that IC is an important determinant of bank's performance. This research is a contribution to the existing literature of intellectual capital and increases the generalizability of Public's Value-Added Intellectual Capital (VAIC) model in the context of a banking industry especially Islamic banking. The results show a significative positive relationship between IC as measured by VAIC and performance of banks measured by ROA ( 0.003 for ROA). The second component of VAIC namely SCE was found to have a positive influence on each component of performance ( 0.057 for ROA and 0.317 for ROE) for the full sample. The performance of various components of VAIC and the overall VAIC score differed between conventional and Islamic banks. Efficiency in capital investment measured through CEE was found to be the most significant predictor of profitability for conventional banks. The findings of this research correspond, relatively, to the literature dealing the issue of association between IC using VAIC approach and performance of banks using ROA and ROE measures (see Setianto \& Sukmana, 2016; Suroso et al., 2017; Muthia et al., 2017). The main limitation of this study is the sample size. Data including listed banks in all countries of GCC would offer a more rigorous representation of the influence of IC on banks' performance, this will be a perspective of another research in line with this study.

\section{References}

Al Matarneh, A.S. (2014), "An Empirical Test of the Effect of Intangible Capital on Financial Performance and Market Value in the Jordanian Companies", Global Journal of Management and Business Research, 14(2), $8-18$.

Bontis N. (1998), "Intangible Capital: An Exploratory Study that Develops Measures and Models", Management Decision, 6(2), 63-76.

Brooking, A. (1997), "The management of intellectual capital”, Journal of Long-Range Planning, 30(3), 364-365.

Cantú, F.J., Bustani, A., Molina, A. \& Moreira, H. (2009), “A knowledge-based development model: The research chair strategy", Journal of Knowledge Management, 13(1), 154-170.

Chen, M., Cheng, S. \& Hwang, Y. (2005), "An empirical investigation of the relationship between intellectual capital and firms' market value and financial performance", Journal of Intellectual Capital, 6(2), 159-176.

Choo C. and Bontis N. (2002), "The Strategic Management of Intellectual Capital and Organizational Knowledge", Oxford University Press, New York.

Edvinsson L. \& Malone M.S. (1997), “Intangible Capital: Realizing Your Company’s True Value by Finding Its Hidden Brainpower", Harper Business.

Gan, K. \& Saleh, Z. (2008), "Intellectual capital and corporate performance of technology-intensive companies: Malaysia evidence", Asian Journal of Business and Accounting, 1(1), 113-130.

Hasan, R., Mohammad, N. \& Alam, M.F. (2017), "Impact of Intellectual Capital on Profitability - Conventional versus Islamic Banks", Journal of Accounting, Finance and Auditing Studies, 3(2), 64-80.

Kamal, M.H.M., Mat, R.C, Rahim, N.A, Husin, N. \& Ismail, I. (?), "Intellectual Capital and Firm Performance of Commercial Banks in Malaysia", Asian Economic and Financial Review, 2(4), 577-590.

Klein, D.A \& Prusak, L. (1994), "Characterizing Intellectual capital. Cambridge", MA, Centre for Business Innovation, Ernst and Young.

Kong E. (2008), "The development of strategic management in the non-profit context: intellectual capital in social service non-profit organizations", International Journal of Management Reviews, 10(3), 281-99.

Latif, M., Malik, M.S. \& Aslam, S. (2012), "Intellectual Capital Efficiency and Corporate Performance in Developing Countries: A Comparison between Islamic and Conventional Banks of Pakistan", Interdisciplinary Journal of Contemporary Research in Business, 4(1),405-420.

Montalan, M.A \& Vincent, B. (2010), "Proposition d'un modèle d'évaluation du capital immatériel pour les organisations transversales à l'hôpital : le cas des Equipes Mobiles de Gériatrie (EMG) ". HAL https://hal.archives-ouvertes.fr/hal-00476676

Muthia, R.L, Rasyid, R. \& Megawati. (2017), “Intellectual Capital and Firm's Performance: An Empirical Evidence from Islamic Bank in Indonesia", JSS, 3(3), 139-148.

Nawaz, T. (2017), "Intellectual Capital, Financial Crisis and Performance of Islamic Banks: Does Shariah Governance Matter?", International Journal of Business and Society, 18(1), 211-226.

Public, A. (1998), "Measuring the Performance of Intellectual Potential in Knowledge Economy", Presented in 1998 at the 2nd McMaster World Congress on Measuring and Managing Intellectual Capital by the Austrian Team for Intellectual Potential. N.p. 
Public, A. (2000), "VAIC an accounting tool for IC management", International Journal of Technology Management, 20(5/6/7/8), 702-714

Ramlall, I. (2009), "Bank-specific, industry-specific and macroeconomic determinants of profitability in Taiwanese banking system: Under panel data estimation", International Research Journal of Finance and Economics, 34(34), 160-167.

Setianto, R.H. \& Sukmana, R. (2016), “Intellectual Capital and Islamic Banks’ Performance; Evidence from Indonesia and Malaysia", Iqtishadia, 9(2), 376-397.

Setyawati, I. (2016), "Determinants of growth and profitability by bank specific variable and market structure in Islamic banking in Indonesia", Academy of Strategic Management Journal, 15(3), 1-14.

Stewart, T.A. (1997), "Intellectual Capital: The New Wealth of Organizations”. Doubleday New York

Sullivan, P.H. (2000), "Valuing intangibles companies an intellectual capital approach", Journal of Intellectual Capital, 1(4), 328-340.

Suroso, S., Widyastuti, T., Salim, M.N. \& Setyawati, I. (2017), "Intellectual Capital and Corporate Governance in Financial Performance Indonesia Islamic Banking”, International Journal of Economics and Financial Issues, 7(4), 96-103.

Tahir, M., Shah, S.Q.A, Khan, M.M. \& Afridi, M.A. (?), "Intellectual Capital and Financial Performance of Banks in Pakistan", The Dialogue, 13(1), 105-118.

Fadma El Mosaid is currently a Professor and researcher in Finance, Economics and Management at National School of Applied Sciences of Ibn Zohr University in the city of Agadir in Morocco. She received her Master's degree in Finance in 2007 from Ibn Zohr University. She received her Ph.D. degree in 2014 from the same institution. Her doctorate study was about Sukuk performance in the field of Islamic finance. She continues her research in the filed of Islamic finance and she is interested in other issues like economic theory and macroeconomic questions. 